\title{
PDC wt Allele
}

National Cancer Institute

\section{Source}

National Cancer Institute. PDC wt Allele. NCI Thesaurus. Code C52903.

Human PDC wild type allele is located in the vicinity of $1 \mathrm{q} 25.2$ and is approximately $18 \mathrm{~kb}$ in length. This allele, which encodes phosducin protein, may be involved in the regulation of both photoreceptor metabolism and light-stimulated visual signaling pathways. 